Research Article

\title{
The Jurisprudence of Human Rights in a Global Context
}

\author{
Matthew Enya Nwocha, PhD, Steve Ahamefula Amaramiro, PhD, Emmanuel Chinweike Ibezim, PhD \\ Faculty of Law, Ebonyi State University, Abakaliki, Nigeria
}

\begin{abstract}
This paper is a study of the conceptual dimensions of human rights gleaned from the writings of scholars and jurists, judicial precedent, and domestic and international human rights instruments, particularly under the United Nations System. Human rights have become an international subject and have today attained the status of a jus cogens rule of international law. The need to determine and clarify the history and dynamics of this subject has given impetus and inspiration to this paper. Applying a theoretical and doctrinal methodology, the paper set out to appraise the different dimensions, and for that matter ramifications, to the concept of human rights and how they affect our everyday life. The paper found, among other things, that human rights law and its observance are much more entrenched at the international forum than in domestic jurisdictions. The paper concluded that human rights issues are no longer a matter of domestic affairs of any nation in the light of extant international instruments to which nations are committed. It therefore recommended that national governments should be more sensitive and responsive to the growing status of human rights as an international subject.
\end{abstract}

Keywords: Human rights, bill of rights, civil liberties, civil and political rights, economic and social rights, collective rights, protocol.

\section{Introduction}

Human rights are claims and entitlements which concentrate on the humanity of man and on man as a member of humankind. Legal scholars and jurists are agreed that human rights are natural to man, standing above the ordinary laws of the land, and antecedent to the political society itself. Human rights are also generally classified into three groups, namely, civil and political rights; economic, social and cultural rights; and group or collective rights. Human rights activists insist that for the individual to fully enjoy human rights, he must be taking the benefit of the three categories. Early traces of human rights are often located within a religious circle. God granted Adam fair hearing in the Garden of Eden when he demanded from him how he came about the consciousness of his nakedness. And in 442 BC, Sophocles in the play Antigone, dramatized about King Creon that all his strength was weakness against the immortal unrecorded laws of God. At this time, there existed a strong intellectual connection between the ideas of natural law and those of the natural rights of man. Hence, a great deal of human rights is conceived from natural law theories. Human rights philosophies and concepts continued to develop up to and through the time of the League of Nations and the United Nations. But it was under the United Nations that it got its strongest boost. Developments across different parts of the globe including nationalist and independence movements also gave foundational impetus and inspiration to the popularization of human rights sensibilities and consciousness. All of these coalesced into a number of international human rights instruments, most of them obligatory on State Parties; while some others, still, were a documentation of extant international customary law and practice and so binding on even non-State Parties as jus cogens rules of international law. Human rights are today considered and universally accepted as a jus cogens rule of international law to the end that its egregious breach anywhere in the globe attracts and should attract action against the violators, particularly under the auspices and through the instrumentality of the United Nations Organization. This paper discusses in detail the origin, nature, development and the contemporary status of human rights in international law. 


\section{Conceptual Framework}

It is worth the exercise to commence a discussion on human rights or any aspect of it with a critical look at the concept. The word human means pertaining to or characterizing man or mankind. ${ }^{1}$ It also means: of or connected with people rather than animals, machines or gods. The word right comes from the Latin word rectus meaning correct, straight, and not crooked. We say that something is right when it agrees with law, morality and justice. Anything which falls below a given standard is said to be wrong. Right means anything to which somebody can lay a just and valid claim. ${ }^{2}$ It may relate to animate or inanimate objects. As such, it could be right to land or right to dignity of human person or right to life or to fair hearing. When someone says he has a right over something, what he means is that everybody else owes him a duty not to violate such right just as he has a duty not to violate the rights of other persons. According to Justice C. A. Oputa:

A right in its most general sense is either the liberty (protected by law) of acting or abstaining from acting in a certain manner, or the power (enforced by law) of compelling a specific person to do or abstain from doing a particular thing. A legal right is thus the capacity residing in one man of controlling, with the assent and assistance of the State, the action of others. It follows then that every right involves a person invested with the right, or the person entitled; a person or persons on whom that right imposes a correlative duty or obligation; an act of forbearance which is the subject-matter of the right, and in some cases an object, that is, a person or thing to which the right has reference, as in the case of ownership. A right therefore is in general, a well founded claim, and when a given claim is recognized by the civil law, it becomes an acknowledged claim or legal right enforceable by the power of the State. ${ }^{3}$

In Afolayan v Ogunride and Ors, ${ }^{4}$ it was held that a right is an interest recognized and protected by the law. In Uwaifo v A.G. Bendel State and Ors, ${ }^{5}$ the Supreme Court held that a legal right is any advantage or benefit conferred upon a person by a rule of law. In Nwankwo and Ors $v$ Onuma and Anor, ${ }^{6}$ the Court stated that the word right means an interest or title in an object or property, a just and legal claim to hold, use or enjoy an object or property. There has been a debate among jurists, publicists, and human rights activists as to the exact definition of human rights. No single universally accepted definition has emerged to date or even foreseen. Human rights are also a victim of the usual difficulties encountered in attempting a definition of any subject or concept. As Niki Tobi put it:

Definitions by their very nature, concept and content, are never accurate like a mathematical solution to a problem. Definitions are definitions because they reflect the idiosyncrasies, inclinations, prejudices and emotions of the person offering them... this is a human problem, which unfortunately has no human solution. As long as our orientations, our backgrounds, and our outlooks remain distinct and distant, the problem will be with us... ${ }^{7}$

In spite of this difficulty, legal writers and jurists have ventured a number of definitions. According to Cranston, a human right is something of which no one may be deprived without a great affront to justice. To him, there are certain deeds, which should never be done, certain freedoms, which should never be invaded,

1. A. S. Hornby. Oxford Advanced Learners Dictionary of Current English. $5^{\text {th }}$ ed. (Oxford: Oxford University Press, 1995) at 526.

2. Okpara Okpara. Human Rights Law and Practice in Nigeria. (Enugu: Chenglo Ltd, 2005) at 36.

3. Chukwudifu Oputa. "Human Rights in the Political and Legal Culture of Nigeria", (Lagos $2^{\text {nd }} \quad$ Idigbe Memorial Lectures, Nigeria Law Publications Ltd, 1989) at 38.

${ }^{4}$. [1990] 1 NWLR (pt. 127) 369 at 391.

5. [1982] 7 SC. 124 at 273.

6. [1994] 5 NWLR (pt. 343) 191 at 204.

. Niki Tobi. Sources of Nigerian Law, (Lagos: Professional Publishers Ltd, 1996) at 14. 
some things which are supremely sacred and human rights are eminently qualified as such. ${ }^{8}$ Although Cranston's definition appears somewhat idealist and imprecise, it was nevertheless adopted by the Supreme Court of Nigeria in Ransome Kuti v A.G. of the Federation ${ }^{9}$ when it stated that a human right:

Is a right which stands above the ordinary laws of the land and which is in fact antecedent to the political society itself. It is a primary condition to a civilized existence, and what has been done by our Constitution since independence is to have these rights enshrined in the Constitution so that the rights could be immutable to the extent of the non-immutability of the Constitution itself.

According to Dowrick ${ }^{10}$, human rights are those claims made by men for themselves or on behalf of other men, supported by some theory, which concentrates on the humanity of man, on man as a human being and a member of humankind. Gasiokwu ${ }^{11}$ has criticized both Cranston's and Dowrick's definitions. To him, Cranston's definition sounds idealistic and lacks precision. Cranston also refers to justice as though it possesses a universal standard, whereas it is a value which varies from society to society. The problem with Dowrick's definition, according to Gasiokwu is that it is ambiguous and has links with natural law philosophy, which in its time was politically motivated. Osita Eze defines human rights as representing demands or claims which individuals or groups make on society some of which are protected by law and have become part of lex lata while others remain aspirations to be attained in the future. ${ }^{12}$ Following Eze's position, human rights are of prime concern in every legal system. It encompasses claims, some of which are enforceable by the law. Thus, right is only right in law because it is recognized and protected as such by the legal system. Either the law gives you right or you do not have it because the law denies you of it. Some rights cannot be enforced because they are mere aspirations to be realized in future. Umozurike has described human rights as those rights which appertain to individuals as human beings and which they expect the society they live or reside in should respect irrespective of their colour, race, religion, sex or other distinctions. ${ }^{13}$ Elsewhere, he defined it as claim which are invariably supported by ethics and which should be supported by law made on society, especially on its official managers, by individuals or groups on the basis of their humanity. ${ }^{14}$ Gasiokwu ${ }^{15}$ states that contemporary human rights can be summarized as claims made on society by individuals and groups, which claims have found expression in objective law, either at national or international levels, and serve as standard for measuring the conditions of human existence, below which no human being should enjoy. Okpara Okpara ${ }^{16}$ has also defined human rights as universally accepted principles and rules that support morality and that make it possible for each member of the human family to realize his or her full potential and to live life in an atmosphere of freedom, justice and peace. Human rights apply to all human beings without any discrimination. They are universal and respect neither boundaries nor State of origin. They fear no political systems and must be upheld at all times for any individual or group in any condition except where they threaten to curtail similar or comparable rights of others. The necessary relationship between human rights and human nature according to natural law creates the essence of universality. And as such human rights enjoy global validity, and apply to all persons regardless of their colour, sex, religion or status in life. This universality theory of human rights is however challenged by the cultural relativism theory which insists that the standards and even the essence of human rights vary according to the culture and the background of the people. Although, the school of cultural relativism is fast declining in favour of the universality principle, exceptions to the universality of human

8. Maurice William Cranston. "Human Rights: Real and Supposed" in Raphael D., ed., Political Theory and the Rights of Man (Bloomington: Indiana University Press, 1967) at 52.

9. [1975] 2 NWLR (pt.6) 211 per Kayode Eso, J.S.C.

${ }^{10}$. F. E. Dowrick, ed., Human Rights, Problems, Perspectives and Texts, (Ashgate Publishing Limited, 1979 ) at 8.

11. Martin Uzochukwu Gasiokwu. Human Rights: History, Ideology and Law (Indiana: Mono Expressions, 2003 ) at 1 and 592.

12. Osita Eze. Human Rights in Africa: Some Selected Problems (Lagos: Macmillan Publishers, 1984) at 5.

13. Oji Umozurike. The Concept of Human Rights (Akanu Ohafia: Co-operative and Rural Development Centre, 2004 ) at 7.

14 . Oji Umozurike. The African Charter on Human and Peoples' Rights (The Hague, Kluwer International, 1997) at 5.

15 . Gasiokwu, supra note 11 at 4.

16 . Okpara, supra note at 40 . 
rights may be found in areas such as marriage. ${ }^{17}$ Nonetheless, according to the Vienna Declaration and Programme of Action, ${ }^{18}$ all human rights are universal, indivisible, interdependent and inter-related.

Human rights are also inalienable. They cannot be curtailed or denied except in circumstances permitted by law such as lawful imprisonment for a crime after due process of trial or the confiscation of property of a judgment debtor. They are those inherent rights of all human beings wherever they are and whomever they are. These rights are not gifts by government or any person. They are attached to a human being wherever he goes. Every human being is therefore, the subject and object of these rights and it is because each human being has intrinsic worth that we talk of fundamental human rights or the inalienable rights of man. Since States do not confer human rights, they cannot withdraw them or take them away permanently from human beings. Rather, States have the duty to promote and protect human rights. This duty is being owed to all persons irrespective of sex, nationality, race, political opinion or social group. It follows that no legal, political, or constitutional authority can annul human rights.

Human rights have been classified into three groups or generations. The first consists of the civil and political rights such as rights to life, dignity, movement, assembly, free speech, fair hearing, and freedom from discrimination. The second is economic, social and cultural rights such as the rights to education, health, work, and social security. The third is referred to as group rights and include the right to selfdetermination, development, rights to freely dispose of natural wealth and resources, and the right to national and international peace and security. ${ }^{19}$ According to Umozurike, the idea of generations of rights does not imply that the earlier generation dies away or gives way to the later but simply indicates that any earlier generation enjoyed international recognition before a later one. All the generations operate at the same time and none may be said to be more important than the others so that for the individual to fully enjoy human rights, he must be taking the benefit of the three categories. ${ }^{20}$

The first traces of human rights may be located within a religious context. As early as 442 B.C., Sophocles in the play Antigone, dramatized about king Creon that all his strength was weakness against the immortal unrecorded laws of God. The laws of God, according to the poet, were higher in authority than the laws of the king or positive law. By the laws of God, Sophocles was referring to natural law, the law of nature and from where the rights of man emanated. At this time there existed a strong intellectual connection between the idea of natural law and that of the natural rights of man. These natural or fundamental rights of man were considered to be those which secured against each individual, the fullest and greatest development of his personality, spirituality, moral and other independence. The law that recognizes and confers these human qualities is the true law which according to Cicero is to be found in right reason, consistent with nature. It was always clear that from inception there existed a clear distinction between natural law and man-made law or positive law. For instance, while it was okay for positive law for slavery to flourish, natural law condemned it. The struggle between the nobles and kings further resulted in the expansion of the dominance of natural law to the detriment of positive law which was held to be subject to natural law in that the kings themselves were made subject to the law of God. For instance, in 1188, the Cortes of Leon secured from King Alfonso IX, a confirmation of a set of rights including the right to the inviolability of life, honour, property and the right to a fair trial. In 1222, the Golden Bull of King Andrew 11 of Hungary guaranteed that no noble would be arrested or ruined without due process. In 1215, King John of England assented to the demands of his barons as contained in the famous Magna Carta. Initially the Magna Carta availed only the nobles but with time everybody in England sought to enjoy the benefits of the Magna Carta.

These piecemeal concessions by the kings to the barons and nobles gave way at the dawn of the 12th century to the doctrine of natural law made available to all. Thinkers like Grotius, Vatel, Pufendorf, and Wolff through the discipline of international law propagated the idea of the rights of man through treaties and as dictated by reason. Among the first of these rights to be given were religious freedoms and the rights of aliens. Subsequently, natural law was invoked by the Puritans, Levellers, and Parliamentarians against the

\footnotetext{
17. In some cultures marriage means, the union of one man and one woman, in others it is the union of one man and several women, in some it involves opposite sexes, in others there are lesbian and homosexual marriages.

18 . Second World Conference on Human Rights, Vienna, June, 1993.

${ }^{19}$. Umozurike, supra note 13 at 3; see also Karel Vasak "For the Third Generation of Human Rights, The Rights of Solidarity", Inaugural Lecture 10th Study Session of the International Institute of Human Rights (Strasbourg 10/9/1979) at 4 and 9. 20 Umozurike, supra note 19 at 3.
} 
Kings in the struggle to democratize the polity and consequently increase on the rights of man. Writers like Locke, Milton, Hall, and Blackstone spoke freely of the immemorial rights of the Englishman. These became the offshoot of the English civil liberties that eventually found their ways into documents like the Petition of Rights, 1628, and the Bill of Rights, 1689. When these radical views spread to colonies of America, it revolutionized the thinking of people and were remolded to read as in the Virginia Declaration of 1776, that all men were by nature equally free and independent and have certain inherent rights. The American Declaration of Independence in 1776 additionally asserted that it is self-evident that all men are created equal, that they are endowed by their Creator with certain inalienable rights, that among these are life, liberty, and the pursuit of happiness. This thought equally permeated the 1791 Bill of Rights, which contained the 10 amendments to the original United States Constitution. The French Declaration of the Rights of Man and the Citizen, 1789, incorporated natural law thoughts and, soon after, the assertion of the rights of man became fashionable in European Constitutions. ${ }^{21}$ These Constitutions claimed they had their inspirations from natural law. As the consciousness for human rights grew, States either acting alone or in collaboration with other States began to intervene in other States ostensibly on humanitarian grounds and through international legal processes, seeking to secure human rights for the inhabitants of such States. In 1827, Britain, France, and Russia took military action against the Ottoman Empire to terminate the complaints of Greece about her nationals suffering under the Turkish administration. In 1860, several States united to end the massacre of Christians in Syria, Jews in Russia and elsewhere. Again, several States especially independent African States united to pressure the United Nations to compel the minority regime in South Africa to stop apartheid and enthrone democracy. As a result of their efforts, apartheid eventually collapsed and democracy was gained in South Africa in 1991. Interventions have also been conducted in Haiti, Uganda, and Panama et. cetera to terminate dictatorial regimes and restore human rights.

Human rights have also been formulated through international treaties of which the earliest known is the treaty of Westphalia, 1668, which sought to establish equality of rights between Protestants and Catholics; the 1774 treaty of Kutchuk Kainarji obliging the Turks to protect the Christians; the Congress of Vienna, 1915 which restored the freedom of worship in Germany and Switzerland to all sects and religions. It must also be pointed out that the creation of the International Labour Organization (ILO) expanded the scope of human rights especially individual and workers' rights such as those related to health, safety, and welfare et. cetera. Again, international conflicts have contributed to the development of human rights. The Geneva Convention For The Amelioration of the Conditions of the Wounded in Times of War, 1864, the Declaration of St. Petersburg, 1868; the Hague Conferences of 1899 and 1907, and the Geneva Conventions of 1949 with their Additional Protocols of 1977 all contributed immensely to humanitarian law which is an integral part of human rights jurisprudence. ${ }^{22}$

Without doubt, the most important source for the development of human rights in modem times is the United Nations. The Charter of the United Nations proclaims faith in fundamental human rights, the dignity of men and women and of nations large and small; promoting and encouraging respect for human rights, and assisting in the realization of human rights and fundamental freedoms as its principal objectives. ${ }^{23}$ Under the Charter, member States pledge to take joint and separate actions in co-operation with the Organization for the achievement of universal respect for and the observance of human rights and fundamental freedoms for all without distinction as to race, sex, language or religion. The duty to protect human rights is vested in the General Assembly of the United Nations. The General Assembly in turn assigns this duty to the Human Rights Commission (now Council) as a specialized Organ. The Commission worked tirelessly over the decades to ensure the promotion and protection of human rights worldwide. In 1948, the Universal Declaration of Human Rights came into being through the work of the then Commission. Although intended to be hortatory and inspirational at the time, the Declaration was soon to become a standard for measuring human rights in Countries of the world. It equally became the mother of the International Covenant on Civil and Political Rights; and the International Covenant on Economic, Social and Cultural Rights, which are binding instruments and provide the working standard for the enforcement of human rights across the world.

21 . For example; Spain, 1802; Sweden, 1809; Norway, 1814; Belgium, 1831; Denmark, 1849; Prussia, 1850.

22. Human Rights Law and Humanitarian Law are opposite sides of the same coin. Human Rights Law deals with human rights in time of peace while Humanitarian Law deals human rights in time of war.

23 . Moses Ikhariala. "The Jurisprudence of Human Rights Law" (Lagos, Journal of Human Rights Law vol. 5, no. 1., 1995) at 81. 
Human rights have properly assumed an international character under the United Nations system. It is one of the items upon which the domestic jurisdiction clause in Article 2 (7) of the Charter cannot apply. As a result, a State cannot plead its domestic jurisdiction to exclude international intervention in cases of reported human rights violations. Today, most nations have made human rights integral aspects of their national constitutions and foreign policy. The granting of aids whether economic, technical or otherwise by well-to-do nations such as the United States, international organizations and agencies is now tied to democracy and respect for human rights. Human rights have assumed their pride of place in international discourse and is a comforting wind that is rapidly blowing across all continents of the World. ${ }^{24}$

The world is by geographical convenience grouped into regions and sub-regions as the case may be. ${ }^{25}$ Taking a clue from the United Nations after the adoption of the Universal Declaration of Human Rights in 1948, most regions of the world made bold efforts to crystallize human rights within their regions for a greater and progressive impact of its widely acknowledged gains. This was more so when the United Nations appeared to have gone into slumber over practical steps in the enforcement of international human rights after its conclusion of the Universal Declaration of Human Rights which spirit and letters were merely hortatory and inspirational at the time of its adoption. The world therefore yearned for a more stringent and binding international law of human rights. The European system, inter-American system, and African system of human rights are among major human rights institutions with definite human rights frameworks that have contributed in large measures to the present body of international human rights law and practice.

The European system for the protection of human rights was established by the Council of Europe, a regional inter-governmental organization created in 1949 by a group of western European nations committed to the preservation of individual freedom and democracy. Article 3 of its statute provides that every member of the Council of Europe must accept the principles of the rule of law and of the enjoyment by all persons within its jurisdiction of human rights and fundamental freedoms. ${ }^{26}$ The Council's human rights system has its legal source in two treaties, namely, the European Convention of Human Rights, and the European Social Charter. The Convention guarantees basic civil and political rights while the Charter proclaims a catalogue of economic and social rights. Each of these treaties established its own institutional framework to supervise compliance. The inter-American human rights system has been developed by the Organization of American States (O.A.S) to promote and protect human rights. The O.A.S is a regional inter-governmental organization, which includes among its estimated 35 members all sovereign States of the Americas. ${ }^{27}$ The inter-American human rights system has two distinct legal sources, the one has evolved from the Charter of the O.A.S, and the other is based on the American Convention on Human Rights. The chart based system applies to all member States of the O.A.S. And the convention system is legally binding only on the States Parties to it. The two systems over-lap and interact in a variety of ways. This makes it difficult at times to determine where one ends and the other begins. In fact, in some cases, the legal mechanisms or norms of both systems apply to different aspects of one and the same human rights situation. The African Charter establishes a system for the protection and promotion of human rights that is designed to function within the institutional framework of the Africa Union. ${ }^{28}$ The African Union is a regional inter-governmental organization, which came into being in 1963 and has current membership of over 60 States. The African Union adopted the African Charter on Human and Peoples' Rights in 1981, and the Charter took effect on October 21, 1986, three months after its ratification by a simple majority of the then O.A.U members as required by Article 63(3) of the Charter. From inception, the African Charter on Human and Peoples' Rights provided for a Commission. By Article 30 of the Charter, the Commission's

24 . Ikhariala, supra note 23 at 84 .

25 . These groupings largely coincide with continents and sub-continents.

26. The end of the cold war has enabled an increasing number of Eastern and Central European nations to join the Council of Europe after declaring their acceptance of the principles spelled out in Article 3.

27. Membership of O.A.S include:- Antigua And Barbuda. Argentina, The Bahamas, Barbados, Belize, Bolivia, Brazil, Canada, Chile, Colombia, Costa Rica, Cuba, Dominica, Dominican Republic, Ecuador, EI Salvador, Grenada, Guatemala, Guyana, Haiti, Honduras, Jamaica, Mexico, Nicaragua, Panama, Paraguay, Peru, St. Kitts And Nevis, St. Lucia, St. Vincent and the Grenadines, Suriname, Trinidad and Tobago, United States, Uruguay, and Venezuela.

28 . Formerly Organization of African Unity (O.A.U). 
function was to promote human and peoples' rights and ensure their protection in Africa. As such, the Commission has promotional and quasi-judicial functions. By Article 45(1), the Commission may also give its views or make recommendations to Governments. The transformation of the Organization of African Unity (O.A.U) to the African Union (A.U) in 2002 , brought several structural and functional changes to the Organization, foremost was the establishment of the African Court of Justice as one of the enforcement mechanisms of the African Charter. Article 18 of the Constitutive Act of the Union establishes the Court while Article 2 of the Protocol of the Court of Justice of the African Union confirms it as the principal judicial organ of the Union. Access to the Court is open to the African Commission, a State Party against whom a complaint is made, a State Party whose citizen is the victim of the violation, a State Party that has lodged the complaint before the Commission and African inter-governmental organizations. Through these human rights treaties and enforcement mechanisms, regional institutions seek to contribute to the overall pool of human rights theory and practice on an international scale. 


\section{The United Nations and Human Rights}

The establishment of the United Nations raised great expectations and hopes in the minds of millions of oppressed peoples the world over who believed that the organization would bring them the freedom and justice for which they had waited so long. As a result, as soon as it came into existence the United Nations began to receive large numbers of petition both from individuals and non-governmental organizations alike alleging violations of human rights and seeking United Nations intervention. ${ }^{29}$ This pent-up desire is understandable bearing in mind that much as the League of Nations strained to provide succor to groups and minorities, such efforts were obviously limited by the traditional international law conceptions of state sovereignty and territorial jurisdiction both of which appeared to swallow up the principles of human rights at the time. As a result of this, there was never a co-ordinated approach to addressing questions of human rights across the globe.

Unfortunately, both the Economic and Social Council (ECOSOC) and the United Nations Commission on Human Rights showed initial reluctance to deal with petitions on human right violations. However, by ECOSOC Resolution 1235 (XLII) of 1967 the Human Rights Commission was permitted to examine certain gross violations of human rights. Again by ECOSOC Resolution 1503 (XLVIII) of 1970, a limited petition system for dealing with communications that reveal a consistent pattern of such violations was established. ${ }^{30}$ ECOSOC Resolution 1235 authorized the Commission and its sub-Commission on Prevention of Discrimination and Protection of Minorities to examine information relevant to gross violations of human rights and fundamental freedoms as exemplified by the policy of apartheid then practiced in South Africa and to racial discrimination as was practiced in the then Southern Rhodesia. When this examination disclosed the existence of situations which reveal a consistent pattern of violations of human rights, the Commission was empowered to undertake a thorough study and to report its conclusions to the Economic and Social Council. Proceedings under Resolution 1235 are public while those under 1503 are confidential. Resolution $1503^{31}$ authorized the Sub-Commission to establish a small working group to examine the communications received from individuals and other private groups by the United Nations so as to identify those that reveal a consistent pattern of gross and reliably attested violations of human rights and fundamental freedoms within the terms of reference of the sub-Commission. The Resolution also provided that the communications together with any relevant comments thereon from the government concerned should be reviewed by the sub-Commission in private meeting with a view to determining whether to refer to the Commission on Human Rights particular situations which seem to reveal a consistent pattern of gross and reliably attested violations of human rights requiring consideration by the Commission.

In 1971, the sub-Commission adopted Resolution 1 (XXIV) establishing specific procedures for the application of ECOSOC Resolution 1503. This resolution set the standard and criteria for admitting a communication. Accordingly, communications became admissible only if there were reasonable grounds to believe that they reveal a consistent pattern of gross and reliably attested violations of human rights and fundamental freedoms. Two implications emerge from this, one that Resolution1503 applies to all situations revealing a pattern of gross violations of human rights wherever they might be committed. Two, that the procedure is applicable to large-scale or systematic denials of human rights rather than to violations of one individual's rights. ${ }^{32}$

A petition received under the 1503 procedure is first examined by a working group of the sub-Commission. The working group may refer it to the sub-Commission which has the power to decide that the petition should be referred to the Commission. The Commission in turn has its own working group which screens the petitions before they are taken up by it. The Commission thereafter identifies the Countries whose conduct it found to be governed by the 1503 procedures. On making the findings, the Commission may refer these situations to the Economic and Social Council. Both the ECOSOC and General Assembly may adopt appropriate resolutions calling on the governments concerned to remedy the situation and comply with their

${ }^{29}$. Thomas Buergenthal. "The United Nations and the Development of Rules Relating to Human Rights." Proceedings of the American Society of International Law (Cambridge: Cambridge University Press, 1965) at 132 and 150.

30. Commission on Human Rights Report to the $50^{\text {th }}$ Session of the United Nations, E/1994/24/E/CH.4/1994/132.

31. See UN Doc E/CN.4/1994/42.

32. The Petitioner does not have to be victim of the violation as long as he or she has direct and reliable knowledge of those violations, sub- Commission Res. 1 (XXIV). 
obligations under the United Nations Charter. ${ }^{33}$ None of the above organs has the power to do more than this and in extreme cases the General Assembly may recommend that the member States impose voluntary sanctions on the recalcitrant government.

Another step towards the strengthening of the United Nations to deal with human rights violations was taken in 1994 when the office of the High Commissioner for Human Rights was created ${ }^{34}$ and a High Commissioner appointed to undertake principal responsibility for United Nations human rights activities under the direction and responsibility of the Secretary-General. Among other things, the High Commissioner is empowered to play an active role in removing the obstacles and in meeting the challenges to the full realization of all human rights and in preventing the continuation of human rights violations throughout the World.

Specialized Conventions of the United Nations have also set up special Human Rights Committees or Commissions to deal with, promote, and enforce the human rights of certain vulnerable groups. Thus, the International Convention on the Elimination of all forms of Racial Discrimination which was adopted by the United Nations General Assembly in 1965 and entered into force in 1969 established a Committee on the Elimination of Racial Discrimination (CERD) composed of 18 members elected by the State Parties but who serve in their individual capacities. The Convention confers a number of functions on the CERD which include the review of the periodic reports which the State Parties have an obligation to prepare on the legislative, judicial, administrative or other measures which they have adopted to give effect to the provisions of the Convention. ${ }^{35}$ The CERD also has the power to deal with inter-state and individual communications. ${ }^{36}$ The procedure for dealing with these communications envisaged a two-stage process. First, the CERD rules on the admissibility of the complaint and goes further to gather all relevant information thereon. Second, an ad hoc conciliation commission is established and charged with the task of preparing a report on the dispute and making appropriate recommendations to the State concerned. ${ }^{37}$

Furthermore, the Convention on the Elimination of all forms of Discrimination against Women (CEDAW) which was adopted by the United Nations in 1979 and entered into force in 1981 established a Committee of 23 experts elected by State Parties but serving in their personal capacities. By periodic reports by the State Parties relating to the legislative, Judicial, administrative or other measures which the States have adopted to give effect to the provisions of the Convention as they have been mandated under Article 18 (1), the CEDAW Committee reports on its activities to the States Parties, the UN Commission on Human Rights, and the General Assembly.

Again, the Convention against Torture and other Cruel, Inhuman or Degrading Treatment which was adopted by the UN General Assembly in 1984 and entered into force in 1987 established the Committee on Torture (CAT) composed of ten independent experts elected by the States Parties to the Convention. Under the torture Convention, the measures for implementation consist of an obligatory reporting system as well as optional inter-state and individual complaint mechanisms which the torture Committee reviews and coordinates. ${ }^{38}$

In addition, the torture Convention empowers the CAT to undertake certain investigatory action on its own initiative. By Article 20, the Committee may initiate an inquiry when it receives reliable information suggesting well-founded indications that torture is being systematically practiced in the territory of a State Party. Although the inquiry is to be confidential and requires the Committee to seek the co-operation of the State Party concerned, the language of Article 20 indicates that the State's failure to co-operate does not deprive the Committee of the right to proceed with the investigation. However, the Committee requires the State's consent to investigate the charges in its territory. When proceedings have been concluded, the Committee may decide to prepare a summary of its findings for inclusion in its annual report which is

33. That is, not to violate human rights. At this stage of the proceedings all debates are public.

34. General Assembly Resolution 48/141 of 7/1/94.

35. See Article 9 of the Racial Convention.

36. Articles 11 and 14.

37. Articles 12 and 13; see also Thomas Buergenthal. "Implementing the UN Racial Convention" Texas International Law Journal Vol. XII, 1977 at 187 and 209; Gomez del Prado. "United Nations Conventions on Human Rights: The Practice of the Human Rights Committee and the Committee on Elimination of Racial Discrimination in Dealing with Reporting Obligations of State

Parties" Human Rights Quarterly Vol. VII (The John Hopkins University Press, 1985) at 492 and 515.

38. Articles 19, 21, \& 22. 
submitted to the States Parties and the UN General Assembly. ${ }^{39}$ By the torture Convention, States Parties are mandated not to extradite a person to a country where he or she would be in danger of being subjected to torture. $^{40}$ Thus, in Mutomba $v$ Switzerland, ${ }^{41}$ the UN Committee on Torture (CAT) decided that Switzerland would violate Article 3 of the Convention were it to expel or return Mr. Mutomba to Zaire where he was in danger of being tortured.

On the basis of Resolution 1235 and 1503, and the vast human rights practice of UN organs implementing them, and subsequent resolutions, there is now established an important legal principle applicable to the interpretation of the UN Charter which is that a State that engages in gross violations of the human rights proclaimed by the Universal Declaration and other relevant human rights instruments violates the UN Charter obligations spelt out in Articles 55 and $56 .{ }^{42}$ It is therefore not illegitimate for the United Nations under Article 2 (7) of the Charter to take appropriate measures designed to compel that State not to engage in gross violations of human rights. Moreso, it is noted that one of the most effective ways to implement human rights is through action within the municipal legal system. Thus, most human rights treaties request that Parties incorporate relevant treaty obligations into their domestic laws and provide appropriate legal remedies. Such obligation to incorporate the relevant treaty into domestic law is contained in Article 2 (2) of the International Covenant on Civil and Political Rights (ICCPR). There is now a preponderance of evidence to show that international law takes precedence over domestic law and this applies to international human rights law. As such, a State cannot invoke its domestic law, for non-observance of her international obligation. ${ }^{43}$ States are therefore obligated to bring their domestic law and practice into conformity with their obligations under international law as failure of a State to incorporate international law into its domestic law has no effect on its international obligation. ${ }^{44}$

Since the creation of the United Nations, one of its cardinal objectives has been the protection and advancement of fundamental human rights. However, attainment of this avowed objective is often a victim of numerous setbacks by way of failure and inaction. This tendency is illustrated most vividly by the frustration suffered by the United Nations Commission on Human Rights, a body established under the United Nations System. The Commission on Human Rights was charged with, among other things, holding public meetings to review the human rights performance of States, and adopting new standards and promoting human rights around the world. Unfortunately, the Commission was pressured into a feckless organization which nations that abused human rights used to block criticism or action to promote human rights. ${ }^{45}$ For example, Countries with poor human rights records successfully sought out seats on the Commission to block scrutiny. Members with dubious human rights records elected to the Commission in its last years included Algeria, China, Cuba, Pakistan, Russia, Saudi Arabia, Sudan, Syria, Vietnam and Zimbabwe. $^{46}$ The disrepute of the Commission grew to a point where the then Secretary-General of the United Nations, Koffi Annan, acknowledged that the Commission's declining credibility had cast a shadow on the reputation of the United Nations system as a whole. He went further to recommend the replacement of the Commission with a new smaller human rights body. Thus the stage was set for a new, more effective United Nations body to address human rights.

By General Assembly Resolution 60/251 of 15 March, 2006, the United Nations created the Human Rights Council with the mandate to address human rights violations across the world and to replace the erstwhile 53-member Commission on Human rights. The 47-Seat Human Rights Council has been elevated to the status of a subsidiary body of the General Assembly unlike its predecessor, the Commission, which was a creation of ECOSOC.

We need also to take into account the area of international humanitarian law where the United Nations through the Hague and Geneva Conventions together with the latter's Additional Protocols I and II has made

\footnotetext{
. Articles 24 and 20 (5).

. See article 3 (1).

See CAT Decision of April 27, 1994, 15 Hum. Rts. L.J. 164 (1994).

. Dealing mainly on international economic and social co-operation; and universal respect for human rights.

Free Zones case ser. AIB, N646 p. 167.

. See the Alabama Arbitration case (1972) More 1 Int. Arb. 495.

45. See United Nations Commission on Human Rights (accessed December 2009) http: //www. Heritage. Org/Research/Worldwide Freedom/h/964. CFM.

46. Libya served as Chairman of the Commission in 2003 despite its ties to the Lockerbie airliner bombing and its own domestic human rights abuses.
} 
strenuous efforts to protect man from atrocities in times of armed conflict. These United Nations Conventions seeking to prevent human rights violations in situations of armed conflict are binding on all nations whether they are members of the UN or not. Any State as well as individuals found to have been involved in war crimes, crimes against humanity, genocide, or crimes against peace as defined in numerous United Nations Conventions and Declarations shall be punished in accordance with United Nations rules. There is the International Criminal Trial for the former Yugoslavia set up by UN Resolution 827 of 1993 to prosecute persons responsible for murder, extermination, enslavement, deportation, imprisonment, torture, rape, persecutions on political, racial and religious grounds, and other inhuman acts in situations of armed conflict whether national or international in character. There is also the Statute of the International Criminal Tribunal for Rwanda set up in 1994 which has the same mandate as above. And the International Criminal Court at the Hague for the trial of war crimes, crimes against peace, and genocide. ${ }^{47}$

\section{Present Status of International Human Rights}

At the level of international law, human rights practice has recorded tremendous progress and advancement especially since the close of the Second World War. Starting with the Universal Declaration of Human Rights, quite a volume of international human rights treaties and conventions have been concluded, adopted and ratified by world nations both under the United Nations Organization and regional platforms. This is cheering because one of the indices of civilization and development is the extent to which a society is prepared to go to advance and sustain the cause of justice, rule of law, and human rights. Sadly, in developing Countries where the majority of the population is poor because they are economically disadvantaged and where the same majority is voiceless because they are politically alienated, concepts such as justice, human rights, and rule of law are taken as luxuries open only to the privileged few and the bourgeoisie.

We may, however, count on the fact that to the extent that treaties provide for certain rights to be protected and for certain actions to be carried out or abstained from, to that extent such performance, observance or abstinence have become issues of proper concern to the Parties to the treaties which issues have been taken out of the exclusive domestic jurisdiction of States. Accordingly, Parties have a legal interest in the observance of the treaties. ${ }^{48}$ In other words, other parties cannot be said to be interfering if they complain about the egregious violations of human rights in a particular jurisdiction. And official spokesmen cannot fend off criticism by claiming that the violation of a right is part of the culture or tradition of a people. As such, Africa or other third world leaders can no longer afford to daub human rights as a western fad which should be ignored. The occurrence of various incidents of breach globally pales in comparison to the enormous progress recorded in international human rights law and practice today. The great number of human rights treaties, its observance that has become part of state practice of any State deserving to be considered civilized and the practice of international institutions have made respect for human rights a jus cogens rule of present international law; meaning that its principles override other rules that run in a contrary direction. It follows, therefore, that human rights have become too important to be left to the whims and caprices of government officials particularly in developing Countries which continually display a propensity, to spawn undemocratic leadership that have a distorted view of modern governance. In the contemporary world order therefore international human rights has assumed a commanding height to the extent that it has become a parameter for measuring international development and the progress of humanity and all scientific, economic and infrastructural, and political development of nations are guided, determined and regulated by universal standards of human rights.

\section{Conclusion}

International human rights law has been defined as the law that deals with the protection of individuals and groups against violations by governments of their internationally guaranteed rights, and with the promotion of these rights. ${ }^{49}$ International human rights law has its historical antecedents in a number of international legal doctrines and institutions. The most important of

\footnotetext{
47. Set up by the Rome Treaty of 1998 .

48. See The Nationality Decrees of Tunis and Morocco (1923) PCIJ Series B- N0. 4 at 27.

49 Thomas Buergental. International Human Rights in a Nutshell, $2^{\text {nd }}$ ed., (Minnesota, West Publishing Co., 1995) at 1 and 357.
} 
these doctrines and institutions are humanitarian intervention, State responsibility for injuries to aliens, protection of minorities, the Mandates and Minorities systems of the League of Nations, and international humanitarian law. To the extent that these doctrines and institutions survive today, they may be said to form an integral part of contemporary international human rights law.

Traditional international law developed various doctrines and institutions that were designed to protect different groups of human beings, namely slaves, minorities, indigenous populations, foreign nationals and so forth. That law and practice provided the conceptual and institutional underpinnings for the development of contemporary international human rights law. Although many of the older institutions and doctrines continue to exist alongside with or have formed an inherent part of modem international law of human rights, in certain other areas this law has been heavily influenced by its antecedents.

At any rate, scholars are unanimous that modern international human rights law differs most significantly from its historical antecedents in that today individual human beings have internationally guaranteed rights as individuals and not as nationals of a particular State unlike the earlier situation where States not individuals were subjects of and had legal rights under international law. There now exist a growing number of international institutions with jurisdiction to protect individuals against human rights violations committed by States of their own nationality as well as by any other States. Although these remedies are often quite inadequate or ineffective, the vast body of international human rights law now in existence and the expanding number of international institutions designed to implement the law have internationalized the subject of human rights in a significant way to the extent that the protection of human rights has become one of the most important items on the agenda of contemporary international economic and political discourse involving governments, intergovernmental organizations and a vast network of non-governmental organizations. Modem international human rights law therefore has been a subject of significant transformation and progressive development.

The United Nations has played a remarkable role in cultivating and promoting human rights to its present status. Regional organizations like the African Union have displayed a loud tendency to follow the footsteps of the United Nations. Sub-regional groupings like ECOWAS have also not been left out as they have adopted treaties and established mechanisms for the protection of human rights. Indeed, human rights have now properly assumed an international character. It is one of the items upon which the domestic jurisdiction clause in Article 2 (7) of the UN Charter cannot apply, to the end that a State cannot plead its domestic jurisdiction to exclude international interventions in cases of reported human rights violations. Today, most nations have made human rights integral aspects of their national Constitutions and foreign policy. The grant of aids, whether economic, technical or military by rich and advanced nations and international organizations and agencies is now tied to democracy and respect for human rights. Human rights have assumed its pride of place in international discourse and is a comforting wind that is rapidly blowing across all continents of the world. The potentials and benefits of sustaining this tempo are many in terms of world peace and security and the economic prosperity of nations.

\section{References}

1. Buergental, Thomas. International Human Rights in a Nutshell, $2^{\text {nd }}$ ed. (Minnesota, West Publishing Co., 1995).

2. Buergenthal, Thomas. "Implementing the UN Racial Convention" (Texas International Law Journal Vol. XII, 1977).

3. Buergenthal, Thomas. "The United Nations and the Development of Rules Relating to Human Rights." Proceedings of the American Society of International Law (Cambridge: Cambridge University Press, 1965).

4. Cranston, Maurice. "Human Rights: Real and Supposed" in Raphael D., ed., Political Theory and the Rights of Man (Bloomington: Indiana University Press, 1967).

5. Dowrick, F. E., ed., Human Rights, Problems, Perspectives and Texts, (Ashgate Publishing Limited, 1979). 
6. Eze, Osita. Human Rights in Africa: Some Selected Problems (Lagos: Macmillan Publishers, 1984).

7. Gasiokwu, Martin Uzochukwu. Human Rights, History, Ideology and Law (Indiana: Mono Expressions, 2001).

8. Hornby, A. S. Oxford Advanced Learners Dictionary of Current English. $5^{\text {th }}$ ed. (Oxford: Oxford University Press, 1995).

9. Ikhariala, M. "The Jurisprudence of Human Rights Law" (Lagos: Journal of Human Rights Law, vol. 5, no. 1., 1995).

10. Tobi, Niki. Sources of Nigerian Law (Lagos: Professional Publishers Ltd, 1996).

11. Okpara, Okpara. Human Rights Law and Practice in Nigeria (Enugu: Chenglo Ltd, 2005).

12. Oputa, Chukwudifu. "Human Rights in the Political and Legal Culture of Nigeria." $2^{\text {nd }}$ Idigbe Memorial Lectures (Lagos: Nigeria Law Publications Ltd, 1989).

13. Prado, Gomez del. "United Nations Conventions on Human Rights: The Practice of the Human Rights Committee and the Committee on Elimination of Racial Discrimination in Dealing with Reporting Obligations of State Parties" Human Rights Quarterly Vol. VII (John Hopkins University Press, 1985).

14. Umozurike, Oji. The Concept of Human Rights (Akanu Ohafia: Co-operative and Rural Development Centre, 2004).

15. Umozurike, Oji. The African Charter on Human and Peoples' Rights (The Hague, Kluwer International, 1997).

16. Vasak, Karel. "For the Third Generation of Human Rights, The Rights of Solidarity", Inaugural Lecture 10th Study Session of the International Institute of Human Rights (Strasbourg 10/9/1979). 